\title{
I Got My Eyes on You: Examination of Sports Celebrity Endorsement Effect on Viewer's Visual Attention
}

\author{
Ümit Can Büyükakgül1 ${ }^{1}$, Arif Yüce ${ }^{2}$, Hakan Katırcı ${ }^{3}$ \\ ${ }^{1}$ ORCID iD: 0000-0002-9463-3073, Eskişehir Technical University, Eskişehir Teknik \\ Üniversitesi 2 Eylül Kampüsü, 26555 Tepebaş1/Eskişehir, Turkey \\ ${ }^{2}$ ORCID iD: 0000-0003-3756-3870, Eskişehir Technical University, Eskişehir Teknik \\ Üniversitesi 2 Eylül Kampüsü, 26555 Tepebaşı/Eskişehir, Turkey \\ ${ }^{3}$ ORCID iD: 0000-0002-2337-7711, Eskişehir Technical University, Eskişehir Teknik \\ Üniversitesi 2 Eylül Kampüsü, 26555 Tepebaş1/Eskişehir, Turkey \\ *Corresponding author, e-mail: arifyuce@eskisehir.edu.tr
}

\begin{abstract}
Celebrity endorsement is a widely used method to gather customer visual attention to the advertised product. Viewers' visual attention to the products is clinical for advertisers. This is why advertisers keep their eyes on consumers to know where they're looking. The study was aimed to explore the visual attention of young sports consumers by gender with the help of an eyetracking system. An experiment was conducted with twenty-eight university students by using Tobii Pro Glasses-2 eye tracker. Fixation durations, counts, and areas were measured to assess the effects of sports celebrity endorsement on visual attention. In major findings, although in the ad where a female sports celebrity was featured, men and women respondents were fixed in similar areas, the men respondents put the maximum focus on the female athlete herself, while the women respondents focus maximum on the product. The present study found that the visual attention of the young sports consumers visual attention to the printed advertisements with sports contents varied by gender. Young consumers can have different connections and associations with celebrities than older consumers. The study gives important information to understand the young sports consumers' visual attention to the printed advertisements which use sport celebrity endorsements.
\end{abstract}

Keywords: Sports Celebrity Endorsement, Customer Visual Attention, Advertisers, Eye-tracking.

\section{Introduction}

Celebrities are known as a leader in effective product promotion strategies for branded products (Muda et al., 2014). Also, sports celebrities and actors are the most used form of celebrity endorsements (Yen \& Teng, 2015). For advertisers, building a personality for products is a very crucial process. To do so, advertisers sometimes use celebrities. The use of celebrities in advertising is a worldwide marketing activity (Alsmadi, 2006; Charbonneau \& Garland, 2005; Katırc1 \& Yüce, 2016; La Ferle \& Choi, 2005; Roy, 2006; Y1lmaz \& Ersavaş, 2005). Sports celebrities are one of the most critical instruments to build a personality for products (Katırc1 \& Yüce, 2016). When the achievements of athletes and perceptions of success in consumers' minds are combined, athletes may take part in the marketing activities of many companies from different sectors (Kim et al., 2017). The image of the athlete combined with concepts of competition, struggle, strength, endurance, and healthiness strengthens the associations of advertised products. The use of sports celebrity endorsement in advertisements can be considered as a contributing factor to both the advertiser's corporate image and the brand image (Kahle \& Homer, 1985; Kambitsis et al., 2002).

Celebrity endorsement is a widely used method to gather customer visual attention

Article History: Received June 09, 2020; Revised December 01, 2020; Accepted February 20, 2021; Published November 05, 2021 
to the advertised product. There are some studies in the field of sports that demonstrate celebrity endorsement in some aspects. For instance, in the study of Zhou et al., (2020), it was revealed that sports celebrity endorsement could affect the brand love of consumers. von Felbert \& Breuer, (2020) found that sports celebrities have a positive effect on consumers' purchasing intention. Further, Felix \& Borges, (2014) analysed that is visual attention related to endorser attractiveness and brand evaluations. As a result of this study, they found that there is a significant relationship between visual attention, endorser attractiveness and brand evaluations. Even though the existence of body of knowledge on visual attention and endorsement effectiveness, this study adds more specific strategies to the field of sports consumption behaviour of young consumers by combining eye-tracking technologies and survey results. As is also understood from all these informations, viewers' visual attention to the products is clinical for advertisers. This is why advertisers keep their eyes on consumers to know where they're looking.

Attracting consumers' attention visually is an important step for both managers and marketers in the realization of purchasing behaviour. In this respect, the necessity of measuring visual attention has become the priority of marketers, advertisers and managers for nearly 100 years. Various systems have been created with scientific studies in this direction and over time these systems have improved and evolved into today's EyeTracking Systems (ETS).

The ETS can be expressed as the sum of the sub-systems created to record and examine the visual attention of people through various technological tools such as tiny cameras and infrared rays. The general purpose of using ETS in marketing research is to understand the psychological, neurological and economical processes that occur in the minds of consumers (N. Lee et al., 2007; Madan, 2010). ETS are one of the technologies that analyse consumers' visual attention and focus on stimuli in advertisements. Analysis of eye movements is one of the neuromarketing techniques used in advertising research (Wang \& Minor, 2008). Neuromarketing, a marketing sub-division that tries to understand the human brain's response to marketing stimuli using neuroscience techniques, refers to the inclusion of data from neuroscience (Senior et al., 2007) and psychophysiology practices in marketing processes (Hubert \& Kenning, 2008). One of the most commonly used biometric measurement techniques in neuromarketing is the examination of pupil movements (Shiv \& Yoon, 2012). With the help of these techniques, it is aimed to better understand and explain the preferences, decisions and behaviours of individuals, and to determine the reasons that lie outside of consciousness (Ariely \& Berns, 2010; N. Lee et al., 2007).

While recording the eye movements of the respondents as raw data, eye tracking tools divide these data into various categories. The most important data among these categories can be referred to as fixation and saccade. Besides, the data referred to as Areas of Interest (AOI) allow the specification of the ways the respondents' visual attention behaves against stimuli (Blascheck et al., 2017). Fixation and saccade movements are the main research elements of the studies in marketing and advertising (Christine Green et al., 2011; Hwang \& Lee, 2018; Van Leeuwen et al., 2017; Wedel \& Pieters, 2000). Fixation refers to the time during which the eye is immobilized on a visual image and provides visual perception (Discombe \& Cotterill, 2015). It is generally known that this fixation time is between 200 and 500 milliseconds (Omur \& Görgülü Aydoğdu, 2017; Rayner, 1998; Wedel \& Pieters, 2000). Another important variable in eye-tracking research is saccade. These eye movements, which take place consciously or 
unconsciously, help to understand for how long respondents have moved their eyes between visual stimuli (Sundstedt, 2010). These movements are also between 10 and 100 milliseconds in general (Deniz Akgül, 2017). Both quantitative and qualitative measures are used in the analysis of eye movements. Quantitative measurements such as fixation number, fixation duration, fixation distribution, and size of saccades, which provide important data to understand the visual strategies of the respondents, appear as the data consulted to understand the semantic perception about the stimulus (Blascheck et al., 2017).

Recent technology-related developments in ETS and decreases in costs have been effective in the intensive use of these systems. ETS, which were previously very expensive, and required much time to install and use, are now easily transportable thanks to their new versions and they can measure eye movements under normal conditions at a cheaper price and more precisely (Wedel \& Pieters, 2000). Thus, ETS are being used more intensively in scientific studies. In parallel with this situation, there has been an increase in the number of studies conducted in the field of sports marketing. It can be said that the studies carried out in this field are concentrated under the main title of sports sponsorship. In these studies, conducted in the field of sponsorship, researches were carried out to understand the visual memory and visual attention of the audience/respondents on the visuals of the sponsors (Boronczyk et al., 2018; Breuer \& Rumpf, 2012, 2015; Lim et al., 2018; Otto \& Rumpf, 2018; Seo et al., 2018). Similar experimental environments were created and, printed ads, in-game ads, on-site ads, animated or text-dominant advertisements, visuals for real or imaginary brands embedded in the video, visuals from sponsors on TV broadcasts were analysed in these studies. During the analysis, the demographic characteristics of the respondents, as well as the differences created on the results by the original and non-original versions of the sponsor's visuals and sports-related information, have been examined. It can be said that the attention of the sports audience is a very important element for advertisers or sponsors, and the variables that affect attention such as colour, animation and their location on the screen or in the field should be examined in detail.

Examining the celebrity endorsement (CE) and ETS studies in the field of advertising, it is clear that the experimental design is supported by survey studies (Muda et al., 2014; Thomson, 2006). While in some studies (Falsarella et al., 2017), the control and test groups were included, in others analysis were performed according to the gender factor within a single sample group (Menon et al., 2016). Also, in other studies, printed ads with and without celebrities (Muda et al., 2014) were compared, and the price effects on the product (Menon et al., 2016) have been investigated. In this context, when the studies in the field of sports are examined; it is seen that these studies are about the examination of sports websites (Lee et al., 2010), effects of athletes' advertisements of non-sports-related products (Banyte et al., 2011), the visual content of the images of the athletes in social networks (Emmons \& Mocarski, 2014), and visual attention on the news postings and athletes' postings on social networks (Vraga et al., 2016).

The objects occupy a place in the visual memory as a whole together with various variables such as their colours, sizes, movements, and compatibility with other objects. All these variables are closely related to the visual attention of individuals as well as how objects are perceived by them. All the visuals we encounter in fields such as television, cinema, magazine, newspaper, billboard etc. are also shaped by these relations. However, advertisers have to 'get their eyes' on consumers' purchasing behaviour to make the most 
profitable decision for advertising actions.

In lots of organizations' advertising campaign, they use different forms of advertisements. Organizations use these advertisements to accomplish their integrated marketing communication goals. Printed advertisements are among the most important tools to gain the attention of targeted market consumers, so we focus on printed advertisements to analyse their effects on consumers' visual attention. In this study, our other main focus is young sport consumers. Younger sport consumers are more likely to seek branded products (Behe et al., 2016). They have different constructures in their relationships with products than older consumers (Ye et al., 2019).

In light of all this information above, the study aims to investigate visual differences of young sport consumers while watching a slideshow that comprised of three printed ads including sports celebrities. Meanwhile, the hypotheses to be tested for this purpose are as follows:

H1: First fixation duration for printed ads with sports celebrities varies by gender.

$\mathrm{H} 2$ : Maximum fixation duration for printed ads with sports celebrities varies by gender.

H3: Fixation count for printed ads with sports celebrities varies by gender.

H4: Fixation area (face, text, logo) for printed advertisements with sports celebrities varies by gender.

\section{Methods}

In this study, three different advertisements with four different sports celebrities (Figure 1) were shown to the respondents and their eye movements were recorded using eye-tracking technology. Eye-tracking data were collected using Tobii Pro Glasses 2 eye tracker. The study was conducted in an eye-tracking laboratory. Simple random sampling methodology was used and 28 university students (14 women and 14 men) took place in this study as respondents. Respondents were chosen if they don't wear glasses or don't have an eye disease. The size of the sample was decided in the base of other studies (Kuisma et al., 2010; Shan et al., 2013) that were conducted under similar experimental design. On the computer screen, a slideshow that contains three printed advertisements was displayed and the respondents viewed the slideshow for 90 seconds on the computer screen. Each advertisement appeared on the computer screen for 30 seconds. Each participant's eye movements were first calibrated with the eye-tracking equipment of Tobii. Not to affect the visual attention of respondents, the aim of the research did not tell before recording ends. That situation is very common in the field of eye-tracking study. In this study, eye movements were decided as indicators of visual attention. These movements were recorded with a frequency of $60 \mathrm{~Hz}$. Tobii Pro Lab software was used for the analysis of eye-tracking data. Assessments of eye-tracking measurements were made by using heat-maps. In addition to the eye-tracking data, a questionnaire consisting of several questions to understand participants' sports consumption behaviour was distributed after eye recording part. These data were analysed to decide whether gender affects the eye movements of participant. 


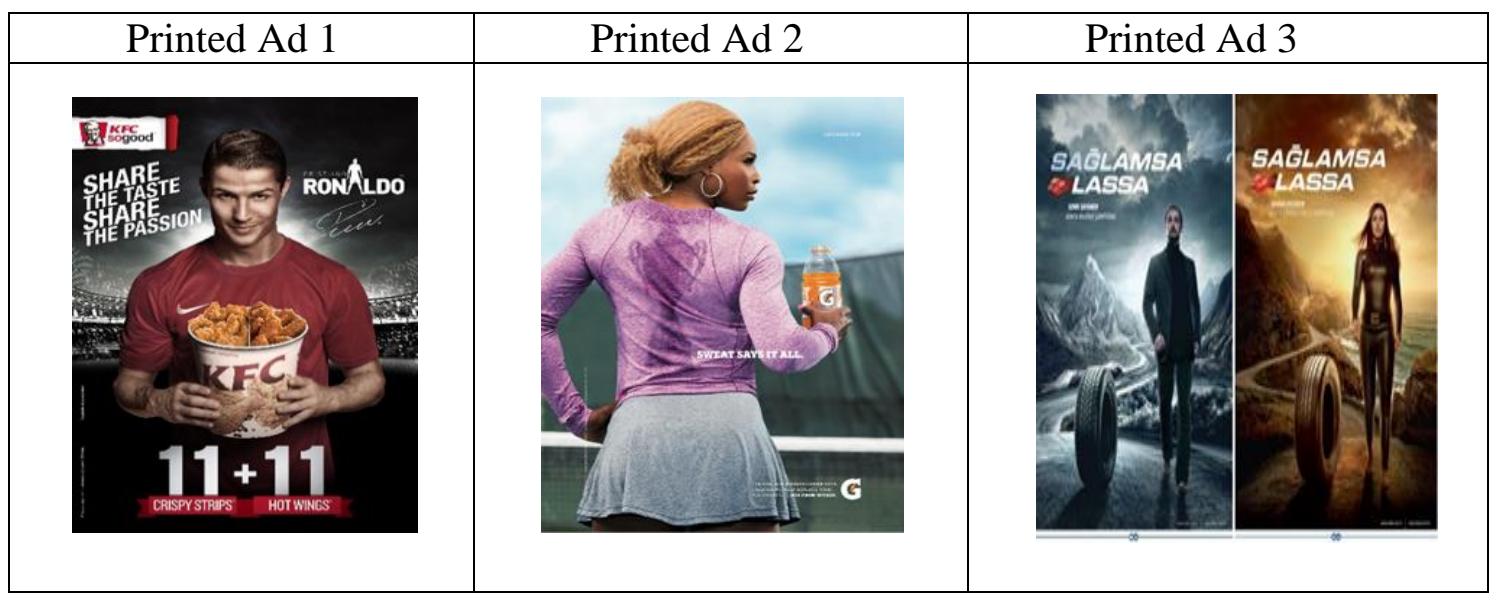

Figure 1. Printed ads that showed in the experiment phase (source:

media.iqads.ro/2014/06/campanie-kfc-cristiano-ronaldo-share-the-taste-share-thepassion-full.jpg; effie.org/case_database/case/NA_2016_441111; huseyinsayin.com/wpcontent/uploads/2014/08/lassa-saglamsa-lassa.jpg)

As seen in Figure 1 in the present study, printed ads with four different sports celebrities (from left to right Cristiano Ronaldo, footballer; Serena Williams, Tennis player; Semih Saygıner, snooker; Şahika Ercümen, diver) were examined. All three ads were consulted by experts before experimenting with their appropriateness. In the figure the first printed ad famous football player C. Ronaldo took place. In the first printed ad, a food and beverage company, there is the signature of Ronaldo, logo and motto of brand and information about a product. All of these variables were effective to decide the printed brand. Such variables considered while choosing the second and third printed ads, too. For instance, an image of trophy on the back of Serena Williams in the second printed ad, and on the third printed ad two globally well-known Turkish athletes representing the solid side of a tire company. Since detailed printed ads allow customers or potential customers to have more option to look at, this type of printed ads were chosen in this study. Such variables like logo, motto, using various colors on the printed ads can affect the visual behaviour of consumers, thus, where the customers are really look and the duration of these becomes more important both for advertisers and sports marketers.

\section{Results}

As a result of the analyses, various eye movement data were obtained for both male and female respondents. These data were then analysed according to the level of interest of the respondents in sports, the ways they follow the games and their frequency of watching the games. In this context, the first fixation time of the respondents in the AOI was examined and the duration of these fixations was compared $\left(\mathrm{H}_{1}\right)$. This comparison was made separately for each ad image. In the light of the information obtained at the end of the analyses, it was determined that the first fixation period for each advertisement visual did not present statistically significant differences by gender $\left(\mathrm{p}_{1}=0.093 ; \mathrm{p}_{2}=0.074\right.$; $\mathrm{p}_{3}=0.550$ ). Thus, hypothesis 1 was not supported.

Secondly, the maximum fixation duration of the respondents on images with different features was examined $\left(\mathrm{H}_{2}\right)$. As a result of the analyses, it was determined that the maximum fixation time of the respondents on individual ads did not present 
statistically significant differences by gender $\left(\mathrm{p}_{1}=0.135 ; \mathrm{p}_{2}=0.118 ; \mathrm{p}_{3}=0.182\right)$. Thus, hypothesis 2 was not supported.

Thirdly, the number of fixations of the respondents on visuals with different features were examined $\left(\mathrm{H}_{3}\right)$. As a result of the analyses, it was determined that the number of fixations that the participants carried out on individual ads did not present statistically significant differences by gender $\left(\mathrm{p}_{1}=0.272 ; \mathrm{p}_{2}=0.894 ; \mathrm{p}_{3}=0.161\right)$. Thus, hypothesis 3 was not supported.

Finally, heat maps have been used to analyse where participants were fixed $\left(\mathrm{H}_{4}\right)$ on ad images (Table 1). Even if the areas appearing on the heat maps are of similar colour and density, the fixation durations will vary between groups. Therefore, it will be more accurate to examine the maximum fixation times in the data (Deniz Akgül, 2017). When the heat maps are examined it was observed in the ad with the male sports celebrity that men fixed at the product while women fixed on the face of the sports celebrity. In the ad where a female sports celebrity was featured, men and women respondents were fixed in similar areas. However, while the men respondents put the maximum focus on the female athlete herself, the women respondents put maximum focus on the product. Both men and women respondents fixed in similar areas while watching the ads with both male and female sports celebrities. Men and women respondents fixed heavily on the area with the texts in the advertisement (Table 1). Thus, hypothesis 4 was accepted.

Table 1. Fixations and Heat-maps of Respondents

\begin{tabular}{ccc}
\hline Variables & Male Respondents & Female Respondents \\
\hline $\begin{array}{c}\text { Total Fixation Count } \\
\text { on All Ads } \\
\begin{array}{c}\text { Average Fixation } \\
\text { Count }\end{array}\end{array}$ & 3204 times & 3345 times \\
& 229 times & 239 times
\end{tabular}

Average Fixation Time throughout the Ads

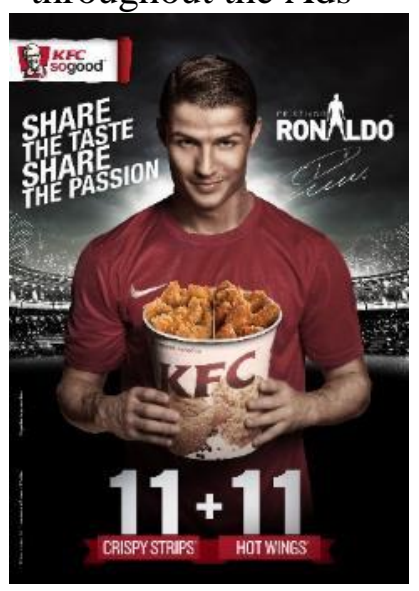

Printed Ad 1

\subsection{3 seconds out of 90}

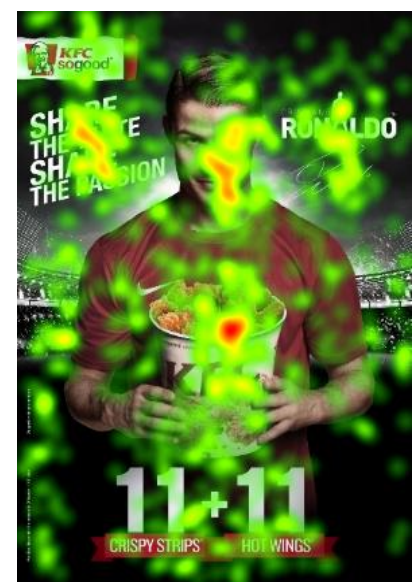

Total Fixation Count 954 times

\subsection{0 seconds out of 90}

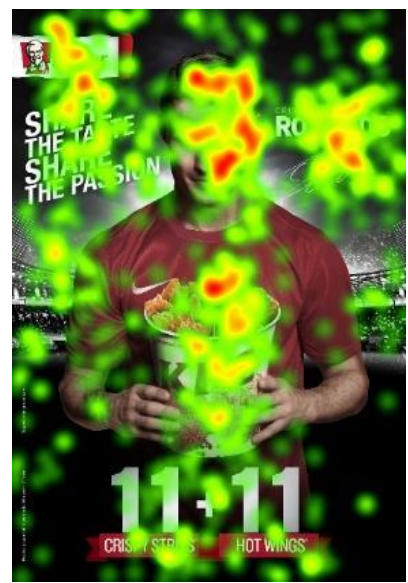

Total Fixation Count 951 times 


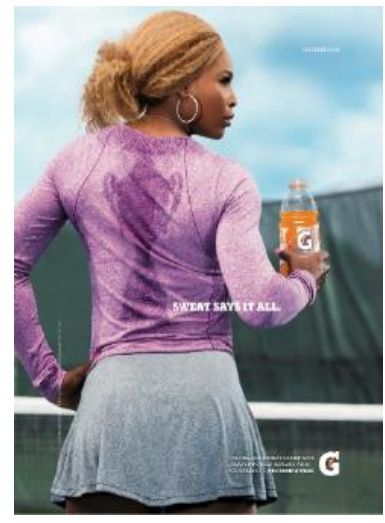

Printed Ad 2

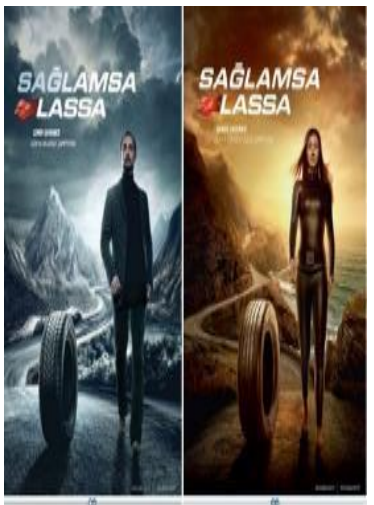

Printed Ad 3

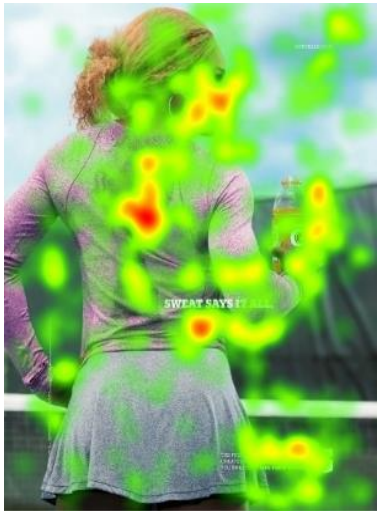

Total Fixation Count 1003 times

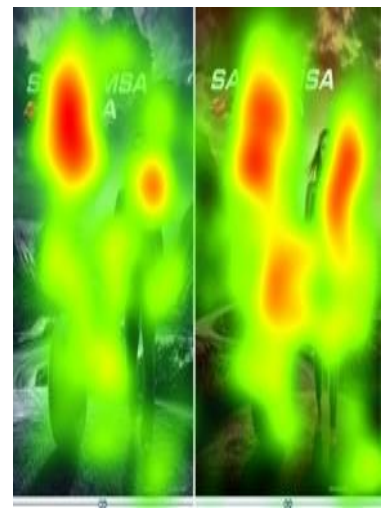

Total Fixation Count 977 times

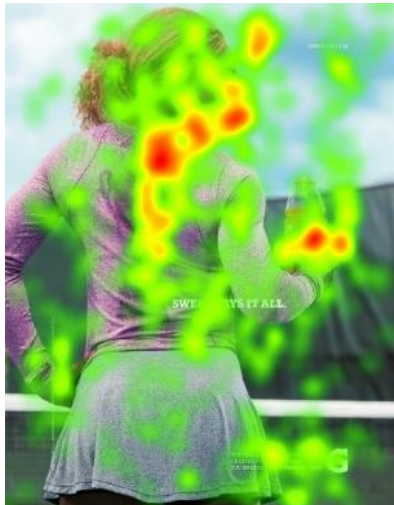

Total Fixation Count 992 times

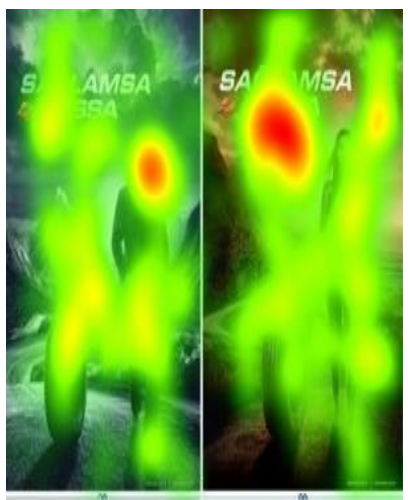

Total Fixation Count 1141 times

Note: Information about fixations and heat-maps on this table were generated by using

Tobii Pro Lab software programme

As seen in the Table 1, total fixation count of young male respondents was 954, on the other hand, it was 951 for young female respondents in the first printed ad. In the second printed ad, it was 1003 for young males and 992 for young females. In the third printed ad, it was 977 for young males and 1141 for young females. Total fixation count on all three printed ads was 3204 for young male respondents, on the other hand it was 3345 for young female respondents. When considered the average fixation count, it was 229 for young males and also 239 for young females. The average fixation time throughout the all three printed ads for young male respondents was 77.93 second (of 90 seconds) and also for young female respondents was 75.70 seconds. Further, it was examined whether there was a significant difference between the duration and number of fixations and active-passive participation in sports activities, the frequency of watching and the means used when watching sports (via media, in the stadium, etcetera). As a result of the analysis, it was found out that there was a significant difference between the followers of sports games on-site (e.g. stadium, sports hall, etcetera) and those who watched it on media only in the advertisement where both male and female celebrities took part $(\mathrm{F}=4.064, \mathrm{p}<0.05)$. It was determined that young sport consumers who watched sports games on media were fixated for a shorter time compared to the ones watching games on site. 


\section{Discussion}

Young male and female sport consumers' fixation data can vary from each other. Gender is one of the most decisive and generally used variables for visual attention in marketing and communication studies (Bindemann et al., 2005; Cerf et al., 2009; Cummins, R. G., Ortiz, M., \& Rankine, 2019; Palermo \& Rhodes, 2007). Gender sometimes can create differences in participant level or stimulus level in the experiment phase. In both cases, gender variables will affect the results of the studies. Briefly in this study, participants' genders were evaluated by using eye-tracking technology. Based on these evaluations, it can be stated that the women respondents fixated more in number but shorter in periods viewing the same ads when compared to men respondents. Men respondents primarily focused on texts, while women respondents focused on the faces on the ads.

In this study, male participants fixated more on the food and texts around Ronaldo, but female respondents heavily on Ronaldo's face and body. Cummins et al. (2019) found similar findings of gender. They made an experiment to decide how much attention a viewer could give to a sports reporter depending on his/her body, face and perceived credibility. They found that the gender of reporters could affect the gaze behaviour (visual attention) of participants positively towards female reporters. Even though the female reporters got more visual attention, they were not more credible than male reporters. Shortly, the gender of the stimuli can help to change the attitudes of participants against the advertised product. In this study, C. Ronaldo's direct and indirect relationship with sports did affect the female participants' visual attention. He has taken part lots of time in both sport-related products (Nike, Herbalife Nutrition) ads and non-sport-related brands like 'Clear' (hair care products/shampoo) and his own brands (CR7, etc.) as well. C. Ronaldo has become a phenomenon and iconic figure not only for fans but also advertisers and sponsors thanks to successful character and career, physical features and exemplary private life as well (Bueter et al., 2019; Hylton \& Lawrence, 2015; Kassing, 2020). In this context, one of the reasons of why female participants fixated more Ronaldo's face and body than men and also focus less on the product in the first stage can be interpreted as the sports celebrity used is C. Ronaldo, who is the one of the most popular in the sports world recently.

It was determined that the women respondents had longer fixations on the ads in which female sports celebrities took part. They fixated on more face of woman sports celebrity and the product. Men respondents focused on a smaller number of different areas when compared to women respondents. They fixated on the image of trophy back side of Serena Williams and texts around her. Women respondents examined the ads with female celebrities more detailed but men respondents fixated more on numbers. While men respondents focused on the woman's figure in ads (Deniz Akgül, 2017) with female celebrities. D Akgül, (2017), tried to find out how different type of printed ads will affect the way people's visual attention. In this research the author showed three different printed ads, one is for women, one is for men and the last one is a sex-driven printed ad with a slightly naked woman on it. Firstly, the same as in our study for all three types of ads male participants spent more time on fixation than female respondents. She found that female respondents were more fixated on products on the ads than males but for the sexdriven ad neither males nor females fixated on the product. These findings are similar to the present study findings. In the present study, we compared male and female celebrities 
on the same printed ad. When the related literature analysed, there is no such study that male and female celebrity compared at the same time as our study. This is one of our study's novelty for the related body of knowledge.

In the third printed ad, there were two globally well-known athletes. The male one was Semih Sayginer also known as 'The Turkish Prince' and 'Mr Magic' in the snooker world and world champion, and the female one was Şahika Ercümen who holds a world record at diving. Both athletes have solid characteristics and successful sport lives. Because of the message of they impersonate, they took part in the advertisement of a tire company that tries to give the message how its tires can manage in all conditions. This ad gave us to compare the visual attention of male and female respondents when they could see both male and female sports celebrities at the same time. Male respondents fixated on heavily texts and then on the body of female sports celebrity. Female respondents fixated more on the face of male sports celebrity's side and fixated on name and texts on the female sports celebrity's side. With these findings, this study will help to fill the gap in the related literature.

Besides the sports celebrity effect, there are some other variables to understand the visual behaviour of young sport consumers about printed ads. In this study, we evaluated some variables that did not take any part in previous studies. These are; a) active/passive participation in sports, b) way of watching sports games (via TV or internet), and c) frequency of watching sports games. The assumption about the way watching sports games can affect the eye movement pattern of young sports consumer about printed ads with sports celebrities was supported but the other two variables could not have supported. Young sports consumers may have longer fixations on printed ads if they follow their favourite athletes'/teams games on site. Also, the credibility of sports celebrity may increase the young sports consumers' attitudes towards athletes and teams. When considered all these, it is obvious that a good combination of the credibility level of sports celebrity and young sports consumers' way of watching sports games can produce desired visual perception for marketers and managers. This situation can be considered as an important and pioneering result since it is not included in other studies in the literature. It may also be more effective for advertising agents, advertisers, and sponsors to determine the content of messages they want to convey based on the point at which the sports activity meets the audience (i.e. media, sports halls, stadiums, etcetera).

\section{Conclusion}

The harmony between sports celebrity and advertised product is an important issue. The equity of a sports celebrity's brand can create a global attraction for the advertised product (Zhou et al., 2020). While choosing a sports celebrity different methods can be used in future studies. For instance, to decide to the credibility level of celebrity, a scale may help to evaluate it. By doing so, researchers will be able to choose the right celebrity as a stimulus for their study. In this study eye-tracking technology was used to understand the visual attention of respondents. EEG (electroencephalography) technology may be used for new studies to have a better understanding of young sports consumers by analysing their brain wave while they are examining a printed or animated ads. Furthermore, consumers' early experiences about advertised product may cause differences in their mind and eye movements. So, these variables such as brand equity, product usage, etc., have to be deeply considered before designing future research. When the related literature is examined, different sample size in previous studies are found in 
ETS studies similarly designed as our study. This situation varies according to the use of time, money and technological elements. The sample size in this study was relatively smaller compared to the sample size of other studies. This is one of the limitations of the study. Working with a larger sample size in future studies will certainly affect the results. The other limitation of this study is that the participants' awareness of the brands and sports celebrities used in the ads were not measured earlier. In future studies, the relationship of these awareness levels with the fixation times should also be considered as a research topic.

\section{Conflict of Interest}

We certify that there is no conflict of interest with any financial, personal, or other relationships with other people or organization related to the material discussed in the manuscript.

\section{Acknowledgements}

The authors would like to thank all participants in this study for their valuable time and sincere interest to the study.

\section{References}

Akgül, D. (2017). Basılı Reklamların Etkisini Cinsiyet ve Gürültü Belirler mi? : Göz Takip Sistemi ile Uygulama. Uluslararası Íktisadi ve İdari İncelemeler, 16, 331348. https://doi.org/https://doi.org/10.18092/ulikidince.321166

Alsmadi, S. (2006). The Power of Celebrity Endorsement in Brand Choice Behavior : An Empirical Study of Consumer Attitudes in Jordan. Journal of Accounting - Business \& Management, 13.

Ariely, D., \& Berns, G. S. (2010). Neuromarketing: The hope and hype of neuroimaging in business. In Nature Reviews Neuroscience (Vol. 11, Issue 4). https://doi.org/10.1038/nrn2795

Banytè, J., Stonkienè, E., \& Piligrimienè, Ž. (2011). Selecting Celebrities In Advertising: The Case Of Lithuanian Sports Celebrity In Non Sport Product Advertisement. Economics and Management, 16, 1215-1224.

Behe, B. K., Huddleston, P., \& Sage, L. (2016). Age cohort influences brand recognition, awareness, and likelihood to buy vegetable and herb transplants. HortScience, 51(2). https://doi.org/10.21273/hortsci.51.2.145

Bindemann, M., Burton, A. M., Hooge, I. T. C., Jenkins, R., \& De Haan, E. H. F. (2005). Faces retain attention. Psychonomic Bulletin and Review, 12(6), 1048-1053. https://doi.org/https://doi.org/10.3758/BF03206442

Blascheck, T., Kurzhals, K., Raschke, M., Burch, M., Weiskopf, D., \& Ertl, T. (2017). Visualization of Eye Tracking Data: A Taxonomy and Survey. Computer Graphics Forum, 36(8), 260-284. https://doi.org/https://doi.org/10.1111/cgf.13079

Boronczyk, F., Rumpf, C., \& Breuer, C. (2018). Determinants of viewer attention in concurrent event sponsorship. International Journal of Sports Marketing and Sponsorship, 19(1). https://doi.org/10.1108/IJSMS-09-2016-0063

Breuer, C., \& Rumpf, C. (2012). The viewer's reception and processing of sponsorship information in sport telecasts. Journal of Sport Management, 26(6). https://doi.org/10.1123/jsm.26.6.521

Breuer, C., \& Rumpf, C. (2015). The impact of color and animation on sports viewers' 
attention to televised sponsorship signage. Journal of Sport Management, 29(2). https://doi.org/10.1123/JSM.2013-0280

Cerf, M., Harel, J., Einhäuser, W., \& Koch, C. (2009). Predicting human gaze using lowlevel saliency combined with face detection. In J. C. Platt, D. Koller, Y. Singer, \& S. T. Roweis (Eds.), Advances in Neural Information Processing Systems 20 (pp. 241--248).

Curran

Associates. https://proceedings.neurips.cc/paper/2007/hash/708f3cf8100d5e71834b1db77dfa1 5d6-Abst

Charbonneau, J., \& Garland, R. (2005). Talent, looks or brains? New Zealand advertising practitioners' views on celebrity and athlete endorsers. Marketing Bulletin, 16.

Christine Green, B., Murray, N., \& Warner, S. (2011). Understanding website useability: An eye-tracking study of the Vancouver 2010 Olympic Games website. International Journal of Sport Management and Marketing, 10(3-4). https://doi.org/10.1504/IJSMM.2011.044793

Cummins, R. G., Ortiz, M., \& Rankine, A. (2019). "Elevator Eyes" in Sports Broadcasting: Visual Objectification of Male and Female Sports Reporters. $\begin{array}{llll}\text { Communication } & \text { Sport, } & 7(6), & 789-810 .\end{array}$ https://doi.org/https://doi.org/10.1177/2167479518806168

Discombe, R., \& Cotterill, S. (2015). Eye tracking in sport: A guide for new and aspiring researchers. Sport \& Exercise Psychology Review, 11(2), 49-58. https://www.researchgate.net/publication/312297582_Eye_tracking_in_sport_A_g uide_for_new_and_aspiring_researchers

Emmons, B., \& Mocarski, R. (2014). She Poses, He Performs: A Visual Content Analysis of Male and Female Professional Athlete Facebook Profile Photos. Visual Communication Quarterly, 21(3). https://doi.org/10.1080/15551393.2014.893752

Falsarella, C. R. B. M., de Oliveira, J. H. C., \& Giraldi, J. de M. E. (2017). The Influence of Celebrity Endorsement on Visual Attention: An Eye-tracking Study in Brazil. Academy of Marketing Studies Journal, 21(1), undefined.

Felix, R., \& Borges, A. (2014). Celebrity endorser attractiveness, visual attention, and implications for ad attitudes and brand evaluations: A replication and extension. Journal of Brand Management, 21(7), 579-593. https://doi.org/https://doi.org/10.1057/bm.2014.24

Hubert, M., \& Kenning, P. (2008). A current overview of consumer neuroscience. Journal of Consumer Behaviour, 7(4-5). https://doi.org/10.1002/cb.251

Hwang, Y. M., \& Lee, K. C. (2018). Using an Eye-Tracking Approach to Explore Gender Differences in Visual Attention and Shopping Attitudes in an Online Shopping Environment. International Journal of Human-Computer Interaction, 34(1). https://doi.org/10.1080/10447318.2017.1314611

Kahle, L. R., \& Homer, P. M. (1985). Physical Attractiveness of the Celebrity Endorser: A Social Adaptation Perspective. Journal of Consumer Research, 11(4). https://doi.org/10.1086/209029

Kambitsis, C., Harahousou, Y., Theodorakis, N., \& Chatzibeis, G. (2002). Sports advertising in print media: The case of 2000 Olympic Games. Corporate Communications: An International Journal, https://doi.org/10.1108/13563280210436763

Katırc1, H., \& Yüce, A. (2016). The Use Of Sports Celebrities In Magazine Advertisement: Case Of GQ Turkey. The Turkish Online Journal Of Design, Art 
and Communication, 18(3), 128-136. https://doi.org/https://doi.org/10.7456/10602100/007

Kim, T., Seo, H. M., \& Chang, K. (2017). The impact of celebrity-advertising context congruence on the effectiveness of brand image transfer. International Journal of Sports Marketing and Sponsorship, 18(3). https://doi.org/10.1108/IJSMS-08-2017095

Kuisma, J., Simola, J., Uusitalo, L., \& Öörni, A. (2010). The Effects of Animation and Format on the Perception and Memory of Online Advertising. Journal of Interactive Marketing, 24(4). https://doi.org/10.1016/j.intmar.2010.07.002

La Ferle, C., \& Choi, S. M. (2005). The importance of perceived endorser credibility in south korean advertising. Journal of Current Issues and Research in Advertising, 27(2), 67-81. https://doi.org/10.1080/10641734.2005.10505182

Lee, N., Broderick, A. J., \& Chamberlain, L. (2007). What is "neuromarketing"? A discussion and agenda for future research. International Journal of Psychophysiology, 63(2). https://doi.org/10.1016/j.ijpsycho.2006.03.007

Lee, W.-Y., Hur, Y., \& Lim, C. (2010). Sport website advertising: the impact of congruity and endorsement on the effectiveness of banner advertising.

Lim, C. H., Hur, Y., \& Song, S. M. (2018). Sponsorship information reception and processing: Explicit and implicit memory of in-game advertising. Social Behavior and Personality, 46(6). https://doi.org/10.2224/sbp.6803

Madan, C. R. (2010). Neuromarketing: the next step in market research? Eureka, 1(1). https://doi.org/10.29173/eureka7786

Menon, R. G. V., Sigurdsson, V., Larsen, N. M., Fagerstrøm, A., \& Foxall, G. R. (2016). Consumer attention to price in social commerce: Eye tracking patterns in retail clothing. Journal of Business Research, 69(11). https://doi.org/10.1016/j.jbusres.2016.04.072

Muda, M., Musa, R., Mohamed, R. N., \& Borhan, H. (2014). Celebrity Entrepreneur Endorsement and Advertising Effectiveness. Procedia - Social and Behavioral Sciences, 130. https://doi.org/10.1016/j.sbspro.2014.04.002

Omur, S., \& Görgülü Aydoğdu, A. (2017). Eye tracking researches and new trends in the field of communication. International Journal of Social Sciences and Education Research, 3(4). https://doi.org/10.24289/ijsser.321815

Otto, F., \& Rumpf, C. (2018). Animation intensity of sponsorship signage: The impact on sport viewers' attention and viewer confusion. Sport, Business and Management: An International Journal, 8(2). https://doi.org/10.1108/SBM-052017-0029

Palermo, R., \& Rhodes, G. (2007). Are you always on my mind? A review of how face perception and attention interact. Neuropsychologia, 45(1), 75-92. https://doi.org/https://doi.org/10.1016/j.neuropsychologia.2006.04.025

Rayner, K. (1998). Eye Movements in Reading and Information Processing: 20 Years of Research. Psychological Bulletin, 124(3). https://doi.org/10.1037/00332909.124.3.372

Roy, S. (2006). An Exploratory Study in Celebrity Endorsements. Journal of Creative Communications, 1(2). https://doi.org/10.1177/097325860600100201

Senior, C., Smyth, H., Cooke, R., Shaw, R. L., \& Peel, E. (2007). Mapping the mind for the modern market researcher. Qualitative Market Research, 10(2). https://doi.org/10.1108/13522750710740826 
Seo, Y. nam, Kim, M., Lee, D., \& Jung, Y. (2018). Attention to eSports advertisement: effects of ad animation and in-game dynamics on viewers' visual attention. Behaviour and Information Technology, 37(12). https://doi.org/10.1080/0144929X.2018.1488993

Shan, S., Mao, Z., Zhou, R., Liu, Z., \& Wu, F. (2013). Streaming Media Advertising: An Empirical Study. Systems Research and Behavioral Science, 30(3). https://doi.org/10.1002/sres.2182

Shiv, B., \& Yoon, C. (2012). Integrating neurophysiological and psychological approaches: Towards an advancement of brand insights. In Journal of Consumer Psychology (Vol. 22, Issue 1). https://doi.org/10.1016/j.jcps.2012.01.003

Sundstedt, V. (2010). Gazing at Games: Using Eye Tracking to Control Virtual Characters. ACM SIGGRAPH 2010 Courses, SIGGRAPH '10. https://doi.org/10.1145/1837101.1837106

Thomson, M. (2006). Human brands: Investigating antecedents to consumers' strong attachments to celebrities. In Journal of Marketing (Vol. 70, Issue 3). https://doi.org/10.1509/jmkg.70.3.104

Van Leeuwen, P. M., De Groot, S., Happee, R., \& De Winter, J. C. F. (2017). Differences between racing and non-racing drivers: A simulator study using eye-tracking. PLoS ONE, 12(11). https://doi.org/10.1371/journal.pone.0186871

von Felbert, A., \& Breuer, C. (2020). How the type of sports-related endorser influences consumers' purchase intentions. International Journal of Sports Marketing and Sponsorship., 22(3), 588-607. https://doi.org/https://doi.org/10.1108/IJSMS-012020-0009

Vraga, E., Bode, L., \& Troller-Renfree, S. (2016). Beyond Self-Reports: Using Eye Tracking to Measure Topic and Style Differences in Attention to Social Media Content. Communication Methods and Measures, 10(2-3). https://doi.org/10.1080/19312458.2016.1150443

Wang, Y. J., \& Minor, M. S. (2008). Validity, reliability, and applicability of psychophysiological techniques in marketing research. Psychology and Marketing, 25(2). https://doi.org/10.1002/mar.20206

Wedel, M., \& Pieters, R. (2000). Eye fixations on advertisements and memory for brands: A model and findings. Marketing Science, 19(4). https://doi.org/10.1287/mksc.19.4.297.11794

Ye, B. H., Barreda, A. A., Okumus, F., \& Nusair, K. (2019). Website interactivity and brand development of online travel agencies in China: The moderating role of age. Journal of Business Research, 99. https://doi.org/10.1016/j.jbusres.2017.09.046

Yen, C. H., \& Teng, H. Y. (2015). Celebrity Involvement, Perceived Value, and Behavioral Intentions in Popular Media-Induced Tourism. Journal of Hospitality and Tourism Research, 39(2). https://doi.org/10.1177/1096348012471382

Y1lmaz, R. A., \& Ersavaş, S. (2005). How does the celebrity work for brand? An analysis on Turkish TV advertising.

Zhou, F., Mou, J., Su, Q., \& Jim Wu, Y. C. (2020). How does consumers' Perception of Sports Stars' Personal Brand Promote Consumers' brand love? A mediation model of global brand equity. Journal of Retailing and Consumer Services, 54. https://doi.org/10.1016/j.jretconser.2019.102012 